\title{
Immediate and one-year outcome of patients presenting with Acute Coronary Syndrome complicated by stroke: Findings from the $2^{\text {nd }}$ Gulf Registry of Acute Coronary Events (Gulf RACE-2)
}

\author{
Jassim Al Suwaidi 1,13*, Khalid Al Habib², Nidal Asaad', Rajvir Singh ${ }^{3}$, Ahmad Hersi ${ }^{2}$, Husam Al Falaeh, \\ Shukri Al Saif ${ }^{5}$, Ahmed Al-Motarreb ${ }^{6}$, Wael Almahmeed ${ }^{7}$, Kadhim Sulaiman ${ }^{8}$, Haitham Amin ${ }^{9}$, Jawad Al-Lawati ${ }^{10}$, \\ Norah Q Al-Sagheer ${ }^{11}$, Alawi A Alsheikh-Ali, ${ }^{7,12}$ and Amar M Salam ${ }^{1}$
}

\begin{abstract}
Background: Stroke is a potential complication of acute coronary syndrome (ACS). The aim of this study was to identify the prevalence, risk factors predisposing to stroke, in-hospital and 1-year mortality among patients presenting with ACS in the Middle East.

Methods: For a period of 9 months in 2008 to 2009, 7,930 consecutive ACS patients were enrolled from 65 hospitals in 6 Middle East countries.

Results: The prevalence of in-hospital stroke following ACS was 0.70\%. Most cases were ST segment elevation MI-related (STEMI) and ischemic stroke in nature. Patients with in-hospital stroke were 5 years older than patients without stroke and were more likely to have hypertension ( $66 \%$ vs. $47.6 \%, P=0.001)$. There were no differences between the two groups in regards to gender, other cardiovascular risk factors, or prior cardiovascular disease. Patients with stroke were more likely to present with atypical symptoms, advanced Killip class and less likely to be treated with evidence-based therapies. Independent predictors of stroke were hypertension, advanced killip class, ACS type -STEMI and cardiogenic shock. Stroke was associated with increased risk of in-hospital (39.3\% vs. 4.3\%) and one-year mortality (52\% vs. $12.3 \%$ ).

Conclusion: There is low incidence of in-hospital stroke in Middle-Eastern patients presenting with ACS but with very high in-hospital and one-year mortality rates. Stroke patients were less likely to be appropriately treated with evidence-based therapy. Future work should be focused on reducing the risk and improving the outcome of this devastating complication.
\end{abstract}

Keywords: Acute coronary syndrome, Myocardial infarction, Stroke, Risk factors, Prognosis

\section{Background}

Stroke is the second leading cause of death worldwide and an estimated 795,000 persons have strokes in the USA each year [1]. There appears to be geographic variation in the incidence of stroke and its recurrence even within the same country [2]. The risk of developing

\footnotetext{
*Correspondence: jalsuwaidi@hotmail.com

'Department of Cardiology, Hamad Medical Corporation (HMC), Doha, Qatar ${ }^{13}$ Department of Adult Cardiology, Heart Hospital, Hamad General Hospital (HMC), P.O Box 3050, Doha, Qatar

Full list of author information is available at the end of the article
}

stroke as a complication of acute coronary syndrome (ACS) is uncommon, however although this risk is decreasing gradually, the mortality rate from this complication is high [3]. Several studies explored risk factors for stroke after ACS and outcome, however these studies were almost exclusively conducted in developed countries, and data from other ethnicities are lacking $[1,3]$. We have recently reported that Middle Eastern patients presenting with ACS are relatively younger and are more likely to have diabetes mellitus and metabolic syndrome when compared to their western counterparts [4-6].

\section{() Biomed Central}

(C) 2012 Al Suwaidi et al.; licensee BioMed Central Ltd. This is an Open Access article distributed under the terms of the Creative Commons Attribution License (http://creativecommons.org/licenses/by/2.0), which permits unrestricted use, distribution, and reproduction in any medium, provided the original work is properly cited. 
Hence, studying stroke in Middle Eastern ACS patients may contribute to our understanding of this complication after ACS. Using data from the First Gulf Registry of Acute Coronary Events (Gulf RACE) we have recently reported low prevalence of stroke associated with high in-hospital complication rates among patients presenting acute myocardial infarction [7]. Here, we review the clinical characteristics, in-hospital and 1-year outcome of stroke patients across the whole spectrum of ACS using data from the Gulf RACE-2.

\section{Methods}

\section{Subjects}

The data were collected from a 9-month prospective, multicenter study of the $2^{\text {nd }}$ Gulf Registry of Acute Coronary Events (Gulf RACE) that recruited 7,939 consecutive ACS patients from 6 adjacent Middle Eastern Gulf countries (Bahrain, KSA, Qatar, Oman, United Arab Emirates, and Yemen) between October 2008 and June 2009. Nine subjects were taken out from the study due to non-ACS cases after final diagnosis. Patients diagnosed with ACS, including unstable angina (UA) and non-ST- and ST-elevation myocardial infarction (NSTEMI and STEMI, respectively), were recruited from 65 hospitals. The study was conducted in compliance with the Helsinki Declaration and ethical approval was obtained the Institutional Review Board and Research and Development Committees of the Ministries of Health in Bahrain, Saudi Arabia, Oman, Qatar, United Arab Emirates and Yemen [8].

On-site cardiac catheterization laboratory was available in $43 \%$ of the hospitals. There were no exclusion criteria, and thus, all the prospective patients with ACS were enrolled. The study received ethical approval from the institutional ethical bodies in all participating countries [8]. Diagnosis of the different types of ACS and definitions of data variables were based on the American College of Cardiology clinical data standards [9].

A Case Report Form (CRF) for each patient with suspected ACS was filled out upon hospital admission by assigned physicians and/or research assistants working in each hospital using standard definitions and was completed throughout the patient's hospital stay. All CRFs were verified by a cardiologist then sent on-line to the principal coordinating center, where the forms were further checked for mistakes before submission for final analysis. An enquiry about patients' survival at 1 and 12 months follow-up after discharged was made.

\section{Definitions}

Stroke was defined as neurologic deficit persisting more than 24 hours. Stroke types; hemorrhagic a stroke with documentation on imaging of hemorrhage in the cerebral parenchyma, or subarachnoid hemorrhage, Ischemic; a focal neurologic deficit that results from a thrombus or embolus (and not due to hemorrhage) or Unknown; if the type of stroke could not be determined by imaging or other means (e.g. from lumbar puncture) or if imaging was not performed $[7,10]$.

\section{Statistical analysis}

Univariate comparisons of patients with and without strokes were made. Continuous variables are presented as means and Standard deviations and compared using the student $\mathrm{t}$ tests or Wilcoxon rank sum tests wherever applicable. Categorical variables are shown as percentages, and compared using the Chi-square tests. Bivariate logistics regressions were used taking age, gender, smoking, diabetes mellitus, hypertension, dyslipidemia, systolic blood pressure, heart rate, creatinine, atrial fibrillation, prior MI, prior CABG, peripheral vascular disease, killip class, ACS type, cardiogenic shock, prior aspirin and statin independent variables to see association with in-hospital stroke, in-hospital mortality and one year mortality. Multivariate logistic regressions with forward selection were applied taking significant predictors at $\mathrm{p}<=0.10$ in bivariate analysis for stroke, in-hospital and one year mortality. Unadjusted and adjusted odds ratios (OR) and 95\% C.I. were calculated. P value $<0.05$ (two tailed) was considered statistically significant at multivariate analysis. Only final multivariate analyses results are provided for in-hospital and one year mortality. Restricted cubic spline functions between SBP and stroke, and SBP and mortality are checked taking quartiles knots of SBP. All analyses were performed using SPSS 18.0 Statistical Package licensed by HMC, Doha, Qatar.

\section{Results}

Of 7,930 patients with ACS in the present analysis, 45.6\% had STEMI and 54.4\% had non-ST elevation acute coronary syndrome. Fifty-six patients (0.7\%) suffered stroke during their index hospitalization. Stroke patients were more likely to present with ST-elevation myocardial infarction (STEMI) $(n=40)$ and less likely to present with NSTEMI $(n=10)$ and unstable angina $(n=6)$. Inhospital stroke was classified as ischemic in 29 patients (52\%). Hemorrhagic stroke occurred in 19 patients (34\%), while in the remaining 8 patients (14\%) stroke type was not identified.

Baseline characteristics of patients with stroke (Table 1).

Patients who suffered in-hospital stroke were about 5 years older than patients without stroke $(62 \pm 12$ vs. $57 \pm 12, P=0.006)$. Stroke patients were less likely to have dyslipidemia $(34.8 \%$ vs. $37.5 \%, P=0.001)$ but were more likely to have hypertension $(66 \%$ vs. $47.6 \%$, $P=0.01)$ and atrial fibrillation (7.1\% vs. $2.1 \%, P=0.008)$. Stroke patients were more likely and to present 
Table 1 Baseline demographics and clinical characteristics for patients with or without prior stroke

\begin{tabular}{|c|c|c|c|}
\hline Variable & No stroke $(n=7,874)$ & Stroke $(n=56)$ & $P$ value \\
\hline \multicolumn{4}{|l|}{ Diagnosis } \\
\hline STEMI / New or presumed LBBB & $45.4 \%$ & $71.4 \%$ & 0.001 \\
\hline NSTEMI & $30.2 \%$ & $17.9 \%$ & \\
\hline Unstable Angina & $24.4 \%$ & $10.7 \%$ & \\
\hline Age in years (mean $\pm S D$ ) & $57 \pm 12$ & $62 \pm 12$ & 0.006 \\
\hline Female gender & $21.2 \%$ & $25 \%$ & 0.5 \\
\hline Body mass index $(\mathrm{kg} / \mathrm{m} 2)($ mean $\pm \mathrm{SD})$ & $27 \pm 5$ & $26 \pm 4$ & 0.20 \\
\hline Current smokers & $52.9 \%$ & $51.8 \%$ & 0.9 \\
\hline Previous angina & $38.4 \%$ & $45.3 \%$ & 0.30 \\
\hline Previous Ml & $19.8 \%$ & $20.8 \%$ & 0.86 \\
\hline Previous $\mathrm{PCl}$ & $9.2 \%$ & $5.6 \%$ & 0.35 \\
\hline Previous CABG & $4.3 \%$ & $3.6 \%$ & 0.8 \\
\hline Diabetes mellitus* & $40.1 \%$ & $43.6 \%$ & 0.6 \\
\hline Hypertensiont & $47.6 \%$ & $66 \%$ & 0.01 \\
\hline Hyperlipidemia & $37.5 \%$ & $34.8 \%$ & 0.001 \\
\hline Family history of CAD & $11.7 \%$ & $8.7 \%$ & 0.53 \\
\hline Previous heart failure & $6.7 \%$ & $13.2 \%$ & 0.06 \\
\hline Atrial fibrillation & $2.1 \%$ & $7.1 \%$ & 0.008 \\
\hline Renal failure & $4.1 \%$ & $3.7 \%$ & 0.89 \\
\hline Peripheral arterial disease & $2 \%$ & $4 \%$ & 0.26 \\
\hline \multicolumn{4}{|l|}{ At presentation } \\
\hline Presentation $>12$ hours & $58.4 \%$ & $41.7 \%$ & 0.1 \\
\hline Ischemic chest pain & $84.3 \%$ & $62.5 \%$ & 0.001 \\
\hline Atypical chest pain & $5 \%$ & $3.6 \%$ & \\
\hline Dyspnea & $7 \%$ & $10.7 \%$ & \\
\hline Killip Class & & & 0.001 \\
\hline Killip class I & $77.2 \%$ & $53.6 \%$ & \\
\hline Killip class II & $14.4 \%$ & $28.6 \%$ & \\
\hline Killip class III & $5.1 \%$ & $5.4 \%$ & \\
\hline Killip class IV & $3.2 \%$ & $12.5 \%$ & \\
\hline Heart rate (beats/min) (mean $\pm S D)$ & $84 \pm 20$ & $90 \pm 19$ & 0.05 \\
\hline Systolic blood pressure $(\mathrm{mm} \mathrm{Hg})($ mean $\pm \mathrm{SD})$ & $135 \pm 29$ & $132 \pm 35$ & 0.44 \\
\hline Diastolic blood pressure $(\mathrm{mm} \mathrm{Hg})($ mean $\pm \mathrm{SD})$ & $81 \pm 17$ & $90 \pm 19$ & 0.05 \\
\hline \multicolumn{4}{|l|}{ GRACE risk score } \\
\hline Low & $39 \%$ & $20 \%$ & 0.001 \\
\hline Intermediate & $39 \%$ & $36 \%$ & \\
\hline High & $22 \%$ & $44 \%$ & \\
\hline \multicolumn{4}{|l|}{ Medications before admission } \\
\hline Aspirin & $40.5 \%$ & $43.6 \%$ & 0.4 \\
\hline Clopidogrel & $12.4 \%$ & $8.9 \%$ & 0.4 \\
\hline B-blockers & $29.1 \%$ & $25 \%$ & 0.5 \\
\hline ACE inhibitors & $25.6 \%$ & $33.9 \%$ & 0.2 \\
\hline Angiotensin-receptor blockers & $4.7 \%$ & $1.8 \%$ & 0.3 \\
\hline
\end{tabular}


Table 1 Baseline demographics and clinical characteristics for patients with or without prior stroke (Continued)

\begin{tabular}{|c|c|c|c|}
\hline HMG-CoA reductase inhibitor & $31.5 \%$ & $30.4 \%$ & 0.9 \\
\hline \multicolumn{4}{|l|}{ Laboratory investigations } \\
\hline Creatinine & $101 \pm 74$ & $140 \pm 124$ & 0.03 \\
\hline
\end{tabular}

Data are expressed as mean or as number (percentage).

* Patient had been informed of the diagnosis by a physician before admission and was undergoing treatment for type 1 or 2 diabetes.

† Systolic blood pressure $>140 \mathrm{~mm} \mathrm{Hg}$, diastolic blood pressure $>90 \mathrm{~mm} \mathrm{Hg}$, or current antihypertensive treatment.

ACE-inhibitors = angiotensin-converting enzyme inhibitors.

\$ Total cholesterol $>6.1 \mathrm{mmol} / \mathrm{L}$, low-density lipoprotein $>4.1 \mathrm{mmol} / \mathrm{L}$, or high-density lipoprotein $<0.9 \mathrm{mmol} / \mathrm{L}$; triglycerides $>200 \mathrm{mg} / \mathrm{dl}$; or current use of lipid-

lowering agent; $\mathrm{MI}=$ myocardial infarction; $\mathrm{PCl}=$ percutaneous coronary intervention; $\mathrm{CAD}=$ coronary artery diseases; $\mathrm{CABG}=\mathrm{Coronary}$ Artery $\mathrm{Bypass} \mathrm{Graft}$.

with atypical cardiac symptoms, advanced Killip class II-IV $(P=0.001)$, higher heart rate $(90$ vs. 84 beat per minute, $P=0.05)$, diastolic blood pressure $(90 \pm 19$ vs. $81 \pm 17 \mathrm{mmHg} ; P=0.05)$ and GRACE risk scoring. There were no significant differences between the two groups in regards to the prevalence of diabetes mellitus, smoking, previous cardiovascular disease, renal failure, peripheral arterial disease or systolic blood pressure. Prior aspirin, clopidogrel, B-blockers, vasodilators and statins were comparable between the 2 groups. Serum creatinine was significantly elevated among stroke when compared to non-stroke patients.

In-hospital Treatment patterns of patients with stroke (Table 2).

The treatment patterns for patients with stroke are presented in Table 2. Stroke patients were less likely to be treated with aspirin, clopidogrel, unfractionated heparin, low molecular weight heparin, glycoprotein IIb/IIIa inhibitors or thrombolytic therapy. Overall use of coronary angiography was low in our registry and its use was even lower among patients who had stroke $(12.5 \%$ vs. $32.6 \%)$. Similar results were found in elective $(1.8 \%$ vs. $10.2 \%$ ) and emergency (3.6\% vs. $4.2 \%$ ) percutaneous coronary interventions (PCI). Stroke patients who were discharged alive were less likely to be prescribed aspirin, clopidogrel, B-blockers, ACE inhibitors and statins at discharge.

In-hospital and One-year outcomes of patients with stroke (Table 3, Figure 1).

Patients who suffered in-hospital stroke were more likely to have their hospital course complicated with recurrent myocardial ischemia (32\% vs. 15\%), recurrent

Table 2 In-hospital therapy and at discharge in patients with or without stroke

\begin{tabular}{|c|c|c|c|c|c|c|}
\hline & \multicolumn{3}{|c|}{ During admission } & \multicolumn{3}{|c|}{ At discharge } \\
\hline & $\begin{array}{l}\text { No stroke } \\
(n=7,874)\end{array}$ & $\begin{array}{c}\text { Stroke } \\
(n=56)\end{array}$ & $P$ value & $\begin{array}{l}\text { No stroke } \\
(n=78744)\end{array}$ & $\begin{array}{c}\text { Stroke } \\
(n=56)\end{array}$ & $P$ value \\
\hline Coronary angiography & $32.6 \%$ & $12.5 \% *$ & 0.002 & & & \\
\hline Percutaneous coronary intervention & $14.5 \%$ & $5.4 \%$ & 0.08 & & & \\
\hline Elective & $10.2 \%$ & $1.8 \%$ & 0.42 & & & \\
\hline Urgent/Emergency PCI (UA/NSTEMI) & $4.2 \%$ & $3.6 \%$ & & & & \\
\hline Aspirin & $98 \%$ & $91 \%$ & 0.001 & $93 \%$ & $57 \%$ & 0.001 \\
\hline$\beta$ blockers & $75 \%$ & $46 \%$ & 0.001 & $80 \%$ & $38 \%$ & 0.001 \\
\hline Clopidogrel & $76 \%$ & $55 \%$ & 0.001 & $68 \%$ & $38 \%$ & 0.001 \\
\hline ACE inhibitors & $25.6 \%$ & $33.9 \%$ & 0.16 & $72 \%$ & $47 \%$ & 0.001 \\
\hline Angiotensin receptor blockers & $4.7 \%$ & $1.8 \%$ & 0.30 & $6.8 \%$ & $1.8 \%$ & 0.1 \\
\hline HMG-CoA reductase inhibitor & $95 \%$ & $89 \%$ & 0.06 & $92 \%$ & $58 \%$ & 0.001 \\
\hline GPIlb/lla inhibitors & $7.8 \%$ & $3.6 \%$ & 0.25 & & & \\
\hline \multicolumn{7}{|l|}{ Thrombolytic therapy } \\
\hline $\mathrm{t}-\mathrm{PA}$ & $3 \%$ & $13 \%$ & 0.09 & & & \\
\hline Streoptkinase & $42 \%$ & $40 \%$ & & & & \\
\hline Reteplase & $44 \%$ & $47 \%$ & & & & \\
\hline Tenektopase & $11 \%$ & $0 \%$ & & & & \\
\hline Unfractionated heparin & $49.5 \%$ & $33.9 \%$ & 0.02 & & & \\
\hline LMWH (enoxaparin) & $39.1 \%$ & $21.4 \%$ & 0.02 & & & \\
\hline
\end{tabular}

Data are expressed as percentage; STEMI = ST elevation myocardial infarction; NSTEMI = non ST elevation myocardial infarction; UA = unstable angina; LBBB = left bundle branch block; $\mathrm{PCl}=$ percutaneous coronary intervention; $\mathrm{LVEF}=$ left ventricular ejection fraction. 
Table 3 In-hospital and one-year outcomes of patients with or without stroke ACS patients

\begin{tabular}{|c|c|c|c|}
\hline Variable & No stroke $(n=7,874)$ & Stroke $(n=56)$ & $P$ value \\
\hline \multicolumn{4}{|l|}{ Hospital outcome } \\
\hline Recurrent ischemia & $15 \%$ & $32 \%$ & 0.001 \\
\hline Reinfarction & $2 \%$ & $10.7 \%$ & 0.001 \\
\hline Congestive heart failure & $12.9 \%$ & $39.3 \%$ & 0.001 \\
\hline Cardiogenic shock & $34 \%$ & $5.6 \%$ & 0.001 \\
\hline Major bleeding & $0.5 \%$ & $12.5 \%$ & 0.001 \\
\hline Predischarge echocardiogram (LVEF < 30) & $76.5 \%$ & $71.4 \%$ & 0.37 \\
\hline Hospital stay (days) & $5.9 \pm 6$ & $13.45 \pm 14$ & 0.001 \\
\hline \multicolumn{4}{|l|}{ Mortality } \\
\hline In-hospital & $4.3 \%$ & $39.3 \%$ & 0.001 \\
\hline 30 day & $7.9 \%$ & $46.3 \%$ & 0.001 \\
\hline One year & $12.3 \%$ & $52 \%$ & 0.001 \\
\hline
\end{tabular}

myocardial infarction ( $10.7 \%$ vs. $2 \%)$, cardiogenic shock (34\% vs. $5.6 \%)$ and major bleeding (12.5\% vs. $0.5 \%)$ compared to those without stroke. Death occurred in $39.3 \%$ of patients who suffered in-hospital stroke compared to $4.3 \%$ of those who did not. Length of stay was significantly longer among stroke compared to non-stroke patients ( 13.5 vs. 5.9 days; $P=0.001)$.

The mortality rate at one month $(46.3 \%$ vs. $7.9 \%$; $P=0.001)$ and one year (52\% vs. $12.3 \% ; P=0.001)$ were significantly higher among stroke patients when compared to non-stroke patients.

Stroke Subtypes (Table 4).

Subset analysis revealed no significant differences between the 3 stroke subtypes in regards to baseline clinical characteristics, MI types or therapies, although there was a trend of increased hemorrhagic stroke among patients treated with thrombolytic therapy.

Multivariate predictors of stroke (Table 5).

Bivariate results showed age $(\mathrm{OR}=1.03$, 95\% C.I.:1.011.05); hypertension ( $\mathrm{OR}=1.87$, 95\% C.I.: 1.09-3.22);

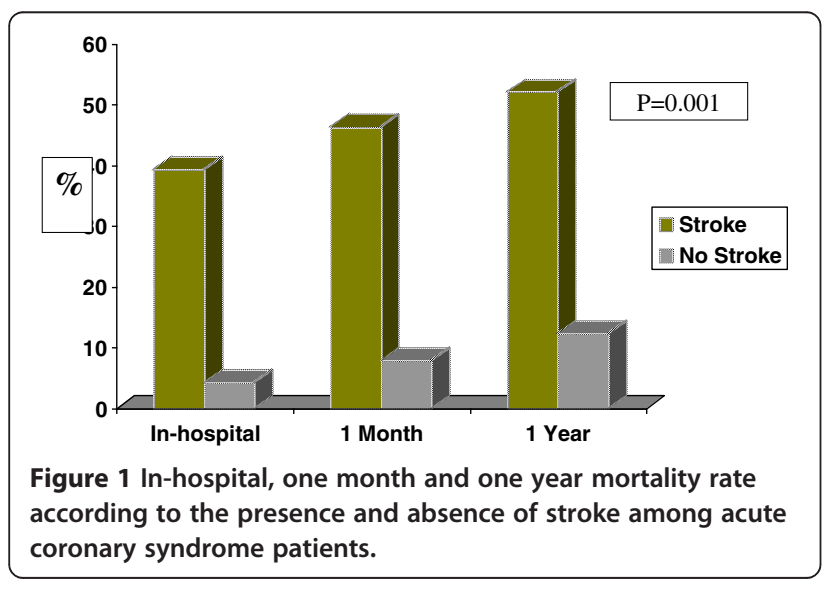

Atrial fibrillation $(\mathrm{OR}=3.70, \quad 95 \% \quad$ C.I.:1.30-10.0); advanced killip class $>1(\mathrm{OR}=2.95$, 95\% C.I.: 1.73-5.0); ACS type STEMI $(\mathrm{OR}=3,95 \%$ C.I.: $1.68-5.38)$; and cardiogenic shock $(\mathrm{OR}=9.15$, 95\% C.I: $5.19-16.12)$ significant variables whereas; advanced killip class, history of hypertension, STEMI and cardiogenic shock were found associated with increased risk of in-hospital stroke in multivariate analysis.

\section{Multivariate predictors of in-hospital death} (Table 6).

All Independent Variables having $\mathrm{p}<=0.10$ at bivariate analysis for in-hospital mortality were considered for multivariate analysis. In-hospital stroke was found independently associated with a significantly higher risk of in-hospital death. The odds of mortality was 42 times higher with $95 \%$ C.I. $(4.09$ - 426.7) in patients with stroke compared to those without stroke.

\section{Multivariate predictors of one-year mortality} (Table 7).

At one year also stroke was found independently associated with a significantly higher risk of mortality having $\mathrm{OR}=13.0$ and $95 \%$ C.I (1.91-81.9) in stroke patients in comparison to non-stroke.

\section{Discussion}

The current study reports low prevalence of stroke among Middle Eastern patients presenting with ACS. $52 \%$ of these strokes were ischemic in origin and $14 \%$ were hemorrhagic. Risk factors of stroke were older age, STEMI presentation, atrial fibrillation and history of hypertension. Stroke patients were less likely to be appropriately treated with evidence-based therapy during hospitalization and at discharge. Although the prevalence of stroke was low and comparable to that of reported registries in Western countries, the 
Table 4 Clinical Characteristics and therapy according to stroke subtypes

\begin{tabular}{|c|c|c|c|c|}
\hline & Ischemic & Hemorrhagic & Not identified & P-value \\
\hline No (\%) & $29(52 \%)$ & 19 (34\%) & $8(14 \%)$ & \\
\hline Age & $60.5 \pm 12$ & $60 \pm 11$ & $67 \pm 15$ & 0.41 \\
\hline Gender Female & $10(34.5)$ & $2(10.5)$ & $2(25)$ & 0.17 \\
\hline Diabetes Mellitus & $16(52.2)$ & $7(36.8)$ & $1(12.5)$ & 0.08 \\
\hline Hypertension & $20(69)$ & $9(47.4)$ & $6(75)$ & 0.23 \\
\hline Atrial fibrillation & $4(13.8)$ & $0(0)$ & $0(0)$ & 0.14 \\
\hline Heart rate & $92 \pm 19$ & $89.9 \pm 15$ & $83 \pm 30$ & 0.54 \\
\hline Systolic blood pressure & $132 \pm 30$ & $139 \pm 35$ & $116 \pm 50$ & 0.29 \\
\hline Diastolic blood pressure & $76 \pm 24$ & $84 \pm 19$ & $68 \pm 32$ & 0.28 \\
\hline STEMI & 20(69) & $16(84.2)$ & $4(50)$ & \\
\hline NSTEMI & $6(20.7)$ & $1(5.3)$ & $3(37.5)$ & \\
\hline UA & $3(0.3)$ & $2(10.5)$ & $1(12.5)$ & 0.34 \\
\hline Coronary Angiogram & $5(17.2)$ & $1(5.3)$ & $1(12.5)$ & 0.30 \\
\hline $\mathrm{PCl}$ & $2(6.9)$ & $1(5.3)$ & $0(0)$ & 0.47 \\
\hline \multicolumn{5}{|l|}{ Medications on admission } \\
\hline Thrombolytic therapy & 10(52.6) & $5(31.2)$ & $0(0)$ & 0.11 \\
\hline Glycoprotein IIb/III inhibitors & $12(41.4)$ & $7(36.8)$ & $6(75)$ & 0.17 \\
\hline aspirin & $26(89.7)$ & 17(89.5) & $8(100)$ & 0.63 \\
\hline Clopidogrel & $15(51.7)$ & $6(31.6)$ & $4(50)$ & 0.37 \\
\hline
\end{tabular}

Table 5 Bivariate and multivariate logistic regression with forward selection for in-hospital stroke patients with acute coronary syndrome

\begin{tabular}{|c|c|c|c|c|}
\hline Variables & Unadjusted OR & 95\% C.I. & Adjusted OR & 95\% C.I. \\
\hline Age & 1.03 & $1.01-1.05$ & - & - \\
\hline Gender Female & 1.24 & $0.67-2.27$ & - & - \\
\hline Smoking & 0.78 & $0.44-1.39$ & - & - \\
\hline Diabetes mellitus & 1.16 & $0.68-1.97$ & - & - \\
\hline Hypertension & 1.87 & $1.09-3.22$ & 2.75 & $1.50-5.26$ \\
\hline Dyslipidemia & 0.89 & $0.50-1.6$ & - & - \\
\hline \multicolumn{5}{|l|}{ Systolic Blood Pressure } \\
\hline$<=120 \mathrm{mmgh}$ & 1 & & & \\
\hline $121-150 \mathrm{mmgh}$ & 1.22 & $0.66-2.26$ & - & - \\
\hline$>=151 \mathrm{mmgh}$ & 1.09 & $0.54-2.22$ & - & - \\
\hline Heart rate (beets /minute) & 1.01 & $1.00-1.02$ & - & - \\
\hline Creatinine (mg/dl) & 1.06 & $0.69-0.84$ & - & - \\
\hline Atrial Fibrillation & 3.70 & $1.30-10.0$ & - & - \\
\hline Prior Ml & 1.06 & $0.50-2.01$ & - & - \\
\hline Prior CABG & 0.83 & $0.20-3.40$ & - & - \\
\hline Peripheral Vascular Disease & 2.00 & $0.50-8.00$ & - & - \\
\hline Killip Class > 1 & 2.95 & $1.73-5.00$ & 1.90 & $1.03-3.50$ \\
\hline ACS type Stemi/LBBB & 3.00 & $1.68-5.38$ & 2.94 & $1.56-5.52$ \\
\hline Cardiogenic Shock & 9.15 & $5.19-16.12$ & 5.72 & $2.96-11.04$ \\
\hline Prior Aspirin & 1.30 & $0.78-2.28$ & - & - \\
\hline Statin within 24 hrs & 0.50 & $0.20-1.07$ & - & - \\
\hline
\end{tabular}


Table 6 Predictors of in-hospital mortality in ACS patients according to Multivariate logistic regression with forward selection

\begin{tabular}{lcc}
\hline Variables & \multicolumn{2}{c}{ In-hospital mortality } \\
\cline { 2 - 3 } & Adjusted OR & $\mathbf{9 5 \% ~ C . I . ~}$ \\
\hline Creatinine $(\mathrm{mg} / \mathrm{dl})$ & 1.47 & $1.27-1.70$ \\
\hline Cardiogenic Shock & 85.48 & $34.5-212.0$ \\
\hline Stroke & 41.75 & $4.09-426.7$ \\
\hline
\end{tabular}

consequences among stroke patients were dismal with $46 \%$ in-hospital mortality and $52 \%$ one-year mortality rates.

The reported prevalence of stroke from studies performed mainly in the Western world varied between as low as $0.31 \%$ to $1.9 \%$ [9-30]. The advent of thrombolysis and primary PCI undoubtedly resulted in significant reduction in stroke risk from $5 \%$ in the 1970 s to $1 \%$ in the current era. The current study reports $0.7 \%$ stroke prevalence among Middle Eastern patients presenting with ACS patients in the current era which consistent with previous reports. On the other hand, $\mathrm{Ng}$ et al. [19] reported a $7.2 \%$ one-year risk of stroke among small population of Chinese MI patients, which is much higher than other reports including ours from a previous registry [7]. When compared to the current study, stroke patients in the National Registry of Myocardial Infarction (NRMI) 3\&4 and the Wercester Heart Attack Study were significantly older ( $>10 \mathrm{yrs}$ ) and less likely to have diabetes mellitus $[3,17]$. Also, while thrombolysis is the main modality of reperfusion therapy in the current registry, significantly more patients received primary PCI in the other studies. The current study suggests that the reduction in stroke risk most likely related to the overall improvement in health care including the provision of evidence-based therapy regardless of the primary reperfusion therapy.

Older age, systemic hypertension, dyslipidemia and ST-elevation myocardial infarction were independent

Table 7 Predictors of one year mortality according to Multivariate logistic regression with forward selection in ACS patients

\begin{tabular}{lcc}
\hline Variables & \multicolumn{2}{c}{ One year mortality } \\
\cline { 2 - 3 } & Adjusted OR & $\mathbf{9 5 \% ~ C . I . ~}$ \\
\hline Age & 1.03 & $1.01-1.05$ \\
\hline Diabetes Mellitus & 1.64 & $1.05-2.56$ \\
\hline Creatinine $(\mathrm{mg} / \mathrm{dl})$ & 1.50 & $1.25-1.82$ \\
\hline Atrial Fibrillation & 5.01 & $1.09-23.1$ \\
\hline Killip Class $>1$ & 1.97 & $1.22-3.18$ \\
\hline Cardiogenic Shock & 8.08 & $4.09-15.9$ \\
\hline Stroke & 12.53 & $1.91-81.9$ \\
\hline
\end{tabular}

risk factors of stroke in our registry. This is consistent with some of the previous reports. Other independent risk factors previously reported in other reports include prior or in-hospital CABG, renal impairment, low body weight and elevated admission heart rate [11-32]. These variability in findings may be attributed to several factors including patients' population, ethnicities, use of thrombolytic therapy versus primary percuatenous revascularization therapy and underscore the need of further international studies that include adequate representations of female gender and various ethnicities [33]. There were no significant differences between patients according to their stroke subtypes in regards to clinical characterstics, MI types or therapies although there a trend of higher use of thrombolytic therapy among hemorrhagic stroke patients.

We observed $39.3 \%$ in-hospital mortality among stroke patients, which is almost 10 times higher than ACS who did not develop stroke. This suggests that although therapeutic advancement in the management of ACS patients has resulted in remarkable improvement in outcome, this improvement in outcome unfortunately was not observed among stroke patients, this underscores the urgent need to study ways to improve this outcome. This is consistent with pervious reports from the developed world, which observed a mortality rate from ischemic stroke of up to $10-40 \%$, and even higher with hemorrhagic stroke. Stroke patients among our patients population were less likely to be treated with evidencebased therapy at admission and on discharge, which may contribute to the high mortality rate at one-year followup. These observations are consistent with that reported by Lee $\mathrm{TC}$ et al. [33].

\section{Limitations}

Our data were collected from an observational study. The fundamental limitations of observational studies cannot be eliminated because of the nonrandomized nature and unmeasured confounding factors. However, well-designed observational studies provide valid results and do not systemically overestimate the results compared with the results of randomized controlled trials. We did not look for risk factors by day of onset. Stroke occurring within first few days may be different from those occurring a week or two later.

\section{Conclusion}

The current study reports low prevalence of stroke among Middle Eastern ACS patients with very high inhospital mortality rate. While older age, anterior MI, hypertension and dyslipidemia at admission were associated with increased risk. Future work should be focused on reducing the risk and outcome of this devastating complication. 


\section{Abbreviations}

ACS: Acute coronary syndrome; Gulf RACE: Gulf Registry of Acute Coronary Syndrome; GRACE: Global Registry of Acute Coronary Events; STEMI: ST elevation myocardial infarction; NSTEMI: Non-ST elevation myocardial infarction; CRF: Case report form; ACE inhibitors: Angiotensin converting enzyme inhibitors; PCl: Percutaneous coronary intervention; CABG: Coronary artery bypass grafting; NRMI: National Registry of Myocardial Infarction.

\section{Competing interests}

The authors declare that they have no competing interests.

\section{Authors' contributions}

JA, KA, NA- participated in the design of the study, patients' recruitment, writing, analyzing and reviewing the paper. RS- performed the statistical analysis. AH, HAF, SAS, WA, HA, JAL, NQA, AAA All-participated in the patients recruitement, analyzing and reviewing the manuscript. All authors read and approved the final manuscript.

\section{Funding}

Gulf RACE is a Gulf Heart Association (GHA) project and was financially supported by Sanofi Aventis, the GHA, Medical Research Center, Hamad Medical Corporation and the College of Medicine Research Center at King Khalid University Hospital, King Saud University, Riyadh, Saudi Arabia. The sponsors had no role in study design, data collection, data analysis, writing of the report, or submission of the manuscript. The study obtained ethical approvals prior to the study.

\section{Acknowledgements}

We thank the staff in all the participating centers for their invaluable cooperation.

\section{Author details}

'Department of Cardiology, Hamad Medical Corporation (HMC), Doha, Qatar. ${ }^{2}$ King Fahad Cardiac Center, King Khalid University Hospital, College of Medicine, Riyadh, Saudi Arabia. ${ }^{3}$ Department of Research, Hamad Medical Corporation (HMC), Doha, Qatar. ${ }^{4}$ Security Forces Hospital, Riyadh, Saudi Arabia. ${ }^{5}$ Saud AlBabtain Cardiac Center, Dammam, Kingdom of Saudi Arabia. ${ }^{6}$ Faculty of Medicine, Sana's University, Sana'a, Yemen. ${ }^{7}$ Department of Cardiology, Sheikh Khalifa Medical City, Abu Dhabi, United Arab Emirates. ${ }^{8}$ Department of Cardiology, Royal Hospital, Muscat, Oman. ${ }^{9}$ Mohammed Bin Khalifa Cardiac Center, Manamah, Bahrain. ${ }^{10}$ Department of NonCommunicable Diseases Surveillance and Control, Ministry of Health, Muscat, Oman. ${ }^{11}$ Cardiac Center, Al-Thawra Hospital, Sana'a, Yemen. ${ }^{12}$ Institute for Clinical Research and Health Policy Studies and Department of Medicine, Tufts Medical Center and Tufts University School of Medicine, Boston, MA, USA. ${ }^{13}$ Department of Adult Cardiology, Heart Hospital, Hamad General Hospital (HMC), P.O Box 3050, Doha, Qatar.

Received: 11 December 2011 Accepted: 9 August 2012

Published: 16 August 2012

\section{References}

1. Dutta M, Hana E, Das P, Steinhub SR: Incidence and prevention of ischemic stroke following myocardial infarction: review of current literature. Cerbebrovasc Dis 2006, 22:331-339.

2. Allen NB, Holford TR, Bracken MB, Goldstein LB, Howard G, Wang Y, Lichtman $\mathrm{JH}$ : Geographic variation in one-year recurrent ischemic stroke rates for elderly medicare beneficiaries in the USA. Neuroepidemiology 2010, 34:123-129.

3. Saczynski JS, Spencer FA, Gore JM, et al: Twenty-year tends in the incidence of stroke complicating acute myocardial infarction. Arch Intern Med 2008, 168:2104-2110.

4. Al Suwaidi J, Zubaid M, El Menyar A, Singh R, Rashed W, Ridha M, Shehab A Al-lawati J, Amin H, Al-Motarreb A: Prevalence of metabolic syndrome in patients with acute coronary syndrome in six Middle-eastern countries. J Clin Hypertens 2010, 12:899-899.

5. El-Menyar A, Zubaid M, Rashed W, Almahmeed W, Al-Lawati J, Sulaiman K, Al-Motarreb A, Amin H, R S, Al Suwaidi J: Comparison of men and women with acute coronary syndrome in six Middle Eastern countries. Am J Cardiol 2009, 104:1018-1022.
6. Al Suwaidi J, Zubaid M, El Menyar A, Singh R, Asaad N, Suliman K, Al Mahmeed W, Al-Shereiqi S, Akbar M: Prevalence and outcome of cigarette and waterpipe smoking among patients with acute coronary syndrome in six Middle-eastern countries. Eur J Prev Cardiol 2012, 19:118-125.

7. Albaker O, Zubaid M, Alsheikh-Ali AA, Rashed W, Alanbaei M, Almahmeed W, Al-Shereiqi SZ, Suliman K, Al Qahtani W, Al Suwaidi J: Early stroke following acute myocardial infarction: incidence, predictors and outcome in six middle-eastern countries. Ceberovasc Dis 2011, 32:471-482.

8. Ali WM, AlHabib KF, Al-Motarreb A, Singh R, Hersi A, Al Faleh H, Asaad N, Al Saif S, Almahmeed W, Suliman K, Amin H, Al-Lawati J, Al Bustani N, AlSagheer NQ, Al-Qahtani A, Al Suwaidi J: Acute coronary syndrome and Khat herbal amphetamine use: an observational report. Circulation 2011, 124:2681-2689.

9. Al Suwaidi J, Reddan DN, Williams K, Pieper KS, Harrington RA, Califf RM, Granger CB, Ohman EM, Holmes DR Jr: Prognostic implications of abnormalities in renal function in patients with acute coronary syndromes. Circulation 2002, 106:974-980.

10. Cannon CP, Battler A, Brindis RG, Cox JL, Ellis SG, Every NR, Flaherty JT, Harrington RA, Krumholz HM, Simoons ML, Van De Werf FJ, Weintraub WS, Mitchell KR, Morrisson SL, Brindis RG, Anderson HV, Cannom DS, Chitwood WR, Cigarroa JE, Collins-Nakai RL, Ellis SG, Gibbons RJ, Grover FL, Heidenreich PA, Khandheria BK, Knoebel SB, Krumholz HL, Malenka DJ, Mark DB, Mckay CR, Passamani ER, Radford MJ, Riner RN, Schwartz JB, Shaw RE, Shemin RJ, Van Fossen DB, Verrier ED, Watkins MW, Phoubandith DR, Furnelli T: American College of Cardiology key data elements and definitions for measuring the clinical management and outcomes of patients with acute coronary syndromes. A report of the American College of Cardiology Task Force on Clinical Data Standards (Acute Coronary Syndromes Writing Committee). J Am Coll Cardiol 2001, 38:2114-2130.

11. Komrad M, Coffey CE, Coffey KS, McKinnis R, Massey EW, Califf RM: Myocardial infarction and stroke. Neurology 1984, 34:1403-1409.

12. Dexter D, Whisnant J, Connolly D, O'Fallon W: The association of stroke and coronary heart disease: a population study. Mayo Clin Proc 1987, 62:1077-1083.

13. Puletti M, Morocutti C, Tronca M, Fattapposta F, Borgia C, Curione M, Cusmano E: Cerebral vascular accidents in acute myocardial infarction. Ital J Neurol Sci 1987, 8:245-248.

14. Behar S, Tanne D, Abinader E, Agmon J, Barzilai J, Friedman Y, Kaplinsky E, Kauli N, Kishon Y, Palant A, the SPRTINT Study Group: Cerebrovascular accident complicating acute myocardial infarction: incidence, clinical significance and short- and long- term mortality rates. The SPRINT Study Group. Am J Med 1991, 91:45-50.

15. Longstreth WT, Litwin PE, Weaver WD: Myocardial infarction, thrombolytic therapy, and stroke. Stroke 1993, 24:587-590.

16. Tanne D, Eicher-Reiss H, Boyko V, Behar S: Stroke risk after anterior wall acute myocardial infarction. Am J Cardiol 1995, 76:825-826.

17. Mooe T, Eriksson P, Stegmayr B: Ischemic stroke after myocardial infarction, a population-based study. Stroke 1997, 28:762-767.

18. Loh E, Sutton MS, Wun CC, Rouleau JL, Flaker GC, Gottlieb SS, Lamas GA, Moyé LA, Goldhaber SZ, Pfeffer MA: Ventricular dysfunction and the risk of stroke after myocardial infarction. N Engl J Med 1997, 336:251-257.

19. Becker R, Burns M, Gore JM, Spencer FA, Ball SP, French W, Lambrew C, Bowlby L, Hilbe J, Rogers WJ, for the National Registry of Myocardial Infarction (NRMl-2) Participants: Early assessment and in-hospital management of patients with acute myocardial infarction at increased risk for adverse outcomes: a nationwide perspective of current clinical practice. Am Heart J 1998, 135:786-796.

20. Wienbergen H, Schiele R, Gitt A, for the MIR and MITRA Study Groups, et al: Incidence, risk factors, and clinical outcome of stroke after acute myocardial infarction in clinical practice. Am J Cardiol 2001, 87:782-785.

21. Ng P, Chan W, Kwan P: Risk of stroke after myocardial infarction among Chinese. Chin Med J 2001, 114:210-211.

22. Kaplan R, Heckbert S, Furberg C, Psaty B: Predictors of subsequent coronary events, stroke, and death among survivors of first hospitalized myocardial infarction. J Clin Epidemiol 2002, 55:654-664.

23. Spencer F, Gore J, Yarzebski J, et al: Trends (1986-1999) in the incidence and outcomes of in-hospital stroke complicating acute myocardial infarction (The Worcester Heart Attack Study). Am J Cardiol 2003, 92:383-388. 
24. Sampson UK, Pfeffer MA, McMurray JJV, for the Valsartan in Acute Myocardial Infarction (VALIANT) Trial Investigators, et al: Predictors of stroke in high-risk patients after acute myocardial infarction: insights from the VALIANT trial. Eur Heart J 2007, 28:685-691.

25. Lichtman JH, Krumholz HM, Wang Y, et al: Risk and predictors of stroke after myocardial infarction among the elderly: Results from the Cooperative Cardiovascular Project. Circulation 2002, 105:1082-1087.

26. Gore JM, Granger CB, Simoons ML, Sloan MA, Weaver WD, White HD, Barbash GI, Van de Werf F, Aylward PE, Topol EJ, Califf RM, MD; for the GUSTO-I Investigators: Stroke after thrombolysis. Mortality and functional outcomes in the GUSTO-I Trial. Circulation 2005, 92:2811-2818.

27. Budaj A, Flasinska K, Gore JM, for the GRACE Investigators, et al: Magnitude of and risk factors for in-hospital and postdischarge stroke in patients with acute coronary syndromes. Findings from a Global Registry of Acute Coronary Events. Circulation 2005, 111:3242-3247.

28. Witt BJ, Brown RD, Jacobson SJ, et al: A community-based study of stroke incidence after myocardial infarction. Ann Intern Med 2005, 143:785-792.

29. Van de Graaff E, Dutta M, Das P, Shry EA, Frederick PD, Blaney M, Pasta DJ, Steinhubl SR: Early coronary revascularization diminishes the risk of ischemic stroke with acute myocardial infarction. Stroke 2006, 37:2546-2551.

30. Maggioni AP, Franzosi MG, Santore E, et al: The risk of stroke in patients with acute myocardial infarction after thrombolytic and antithrombotic treatment. Gruppo Italiano per lo Studio della sopravvivenza nell'Infarto Micardico II (GISSI-2), and The International Study Group. New Eng J Med 1992, 327:1-6.

31. Cronin L, Mehta SR, Zhao F, et al: Stroke in relation to cardiac procedures in patients with non-ST elevation acute coronary syndrome: A study involving >18000 patients. Circulation 2001, 104:269-274.

32. Lee TC, Goodman SG, Yan RT, Grondin FR, Welsh RC, Rose B, Gyenes G, Zimmerman RH, Brossoit R, Saposnik G, Graham JJ, Yan AT, Canadian Acute Coronary Syndromes I and II, Canadian Global Registry of Acute Coronary Events (GRACE/GRACE2), and the Canadian Registry of Acute Coronary Events (CANRACE) Investigators: Disparities in management patterns and outcomes of patients with non-ST-elevation acute coronary syndrome with and without a history of cerebrovascular disease. Am J Cardiol 2010, 105:1083-1089.

33. Foerch C, Czapowski D, Misselwitz B, Steinmetz H, Neumann-Haefelin T, Arbeitsgruppe Schlaganfall Hessen (ASH): Gender imbalances induced by age limits in stroke trials. Neuroepidemiology 2010, 35:226-230.

doi:10.1186/1471-2261-12-64

Cite this article as: Al Suwaidi et al:: Immediate and one-year outcome of patients presenting with Acute Coronary Syndrome complicated by stroke: Findings from the $2^{\text {nd }}$ Gulf Registry of Acute Coronary Events (Gulf RACE-2). BMC Cardiovascular Disorders 2012 12:64.

\section{Submit your next manuscript to BioMed Central and take full advantage of:}

- Convenient online submission

- Thorough peer review

- No space constraints or color figure charges

- Immediate publication on acceptance

- Inclusion in PubMed, CAS, Scopus and Google Scholar

- Research which is freely available for redistribution 